\title{
CONSIDERAÇÕES SOBRE O RELACIONAMENTO CONJUGAL DA MULHER GRAVIDA
}

\author{
Margarita Antonia Villar Luis*
}

LUIS, M.A.V. Consideraçōes sobre o relacionamento conjugal da mulher grávida. Rev. Esc. Enf. USP, São Paulo, 20(2):125-142, 1986.

A autora discorre sobre as dificuldades de relacionamento conjugal da mulher grávida, ressaltando a complexidade do assunto, em decorrência das diversas variáveis incluidas na origem dos problemas apresentados e tece algumas consideracoues sobre as peculiaridades a serem observadas na assistência à gestante.

\section{INTRODUÇÃO}

Quando iniciamos nosso trabalho de assistência de Saúde Mental às gestantes já tínhamos noções a respeito de algumas possiveis causas de tensão durante o período gravídico, amplamente abordadas por diversos autores, dentre eles, CAPLAN ${ }^{1}$, que enquadrou esse acontecimento como sendo uma crise evolutiva no ciclo vital da mulher.

MALDONADO 7, seguindo essa mesma linha de pensamento, enriqueceu seu discurso com reflexões sobre a importância em ser o pai do bebê incluído na assistência à maternidade; também, acrescentou ao tema gravidez, colocações de fundo psicanalítico que foram abordadas com maior profundidade, por DEUTSCH ${ }^{3}$, LANGER ${ }^{5}$ e SOIFER ${ }^{10}$, autoras de formação analítica que se dedicaram ao estudo dos aspectos da gravidez sob o ponto de vista da psicanálise.

No decorrer de nosso atendimento tivemos conhecimento de fatos da intimidade dessas mulheres que, em algumas circunstâncias, extrapolavam as dificuldades próprias da gravidez, descritas pela literatura. A vivência nos permitiu conhecer toda uma gama de ocorrências na história de vida dessas pacientes e familiares que constituiram uma característica própria dessa população. Notamos que suas carências e dificuldades existenciais refletiam a problemática do meio cultural e social de onde as pacientes provinham e que em muitos casos a gravidez àpenas agravava.

\footnotetext{
- Enfermeira. Mestre em Enfermagem. Professor Assistente do Departamento de Enfermagem Psiquíatrica e Clências Humanas da Escola de Enfermagem de Ribeirão Preto - USP.
} 
Baseada nos depoimentos de nossas gestantes, observamos que, dentre as ocorrências geradoras ou potencializadoras da tensão durante o período gravídico, estava o relacionamento com o pai do bebê. As gestantes, durante as entrevistas, freqüentemente apresentavam, com relação a seus companheiros, expressões de revolta, mágoa, frustração, impotência, preocupação quanto ao futuro e medo de abandono; sentimentos que eram uma reação manifesta de uma realidade conjugal e de vida que não estava atendendo às suas necessidades de amor, conforto, diálogo, escolha, conhecimento e de partilha de responsabilidades.

Acreditamos que o relacionamento da gestante com o pai do bebê é o fator que melhor caracteriza esse contexto de vida da mulher grávida, uma vez que abrange os aspectos psíquicos e afetivos únicos de cada membro, os aspectos da dinâmica do relacionamento entre o casal e demais membros, e as suas relações sociais com o meio ambiente.

Assim, essa atividade assistencial nos forneceu dados importantes sobre a realidade vivenciada pela gestante, não só em termos da constatação da ocorrência das alterações clássicas na mulher durante a gravidez, como também nos alertou para a problemática do relacionamento com o pai do bebê, inserida num contexto existencial mais amplo, a qual pode interferir no desconforto e ansiedade da gravidez e agravá-los.

Com base em nossa experiência sentimos que o relacionamento da gestante com seu companheiro, dada a sua relevância, não pode ser ignorado, omitido ou desvalorizado, na ordem de prioridades, na programação de assistência de enfermagem às gestantes; assim este trabalho tem por objetivo mostrar os achados sobre o assunto, obtidos com nossa população, e o intuito de despertar o interesse dos enfermeiros e demais profissionais envolvidos nessa assistência, para o tema em questão.

\section{PROCEDIMENTO}

Oferecemos atendimento de Enfermagem a gestantes, com maior enfoque em saúde mental, à população de três serviços comunitários da região de Ribeirão Preto (Centros de Saúde e Centros Espíritas), durante um período de 15 meses. Nessa assistência não selecionamos as pacientes segundo paridade, raça, estado civil, ocupação e outras características particulares, pois o nosso interesse estava voltado para os aspectos gerais que poderiam ser focos de tensão.

As pacientes eram atendidas inicialmente através da Abordagem Geral, forma de assistência utilizada na intervenção em crise, que implica em atender as expectativas e dificuldades de uma população sujeita a um tipo específico de crise (JACOBSON et alii ${ }^{4}$ ). Em nosso caso, as pacientes passavam pela mesma situação crítica vital - a gravidez. Essa assistência era oferecida em reuniōes de grupo (LUIS ${ }^{6}$ ).

Durante as atividades grupais observamos que algumas pacientes não estavam respondendo suficientemente aos procedimentos utilizados 
nessa abordagem; nesse caso as gestantes eram atendidas através da Abordagem Individual (LUIS ${ }^{6}$ ).

Esta outra forma de assistência, não mais se preocupa com uma crise que atinge determinada população; ao contrário, seu alvo é atender às expectativas e dificuldades próprias de um ínico indivíduo em crise (JACOBSON et alii ${ }^{4}$ ).

Com a finalidade de organizar nosso atendimento individual, denominamos Orientações Esporádicas; a assistência que ofereciamos as pacientes em entrevistas eventuais não sistemáticas, a assistência prestada através de acompanhamento sistemático de entrevistas denominamos Seguimento de Enfermagem (LUiS ${ }^{6}$ ).

A sistematização dessas entrevistas dependia do grau de dificuldade da situação apresentada pela paciente e da sua aceitação em se submeter a essa atividade.

Durante o periodo mencionado 52 gestantes foram triadas para a Abordagem Individual; dessas, 34 nos deram claramente indícios de que o seu relacionamento com o marido ou companheiro* era conflituoso.

$O$ material que analisamos neste trabalho se refere aos dados obtidos com essas 34 gestantes, durante o periodo de atendimento.

\section{CARACTERISTICAS DA POPULAÇÃO}

Com a finalidade de caracterizar melhor essas 34 pacientes de nossa população fornecemos, no Quadro I, alguns dados adicionais a respeito da suas peculiaridades.

Nele observamos que há o predomínio das mulheres do estado civil casado (23) em relação às amasiadas (9) e às solteiras (2). Na faixa etária são mulheres gestantes entre 17 e 39 anos, portanto ainda no seu período de fertilidade. Quanto à ocupação a grande maioria executa serviços domésticos.

Sobre os problemas expostos pelas pacientes durante a assistência, notamos que a gravidez aparece direta ou indiretamente relacionada às dificuldades do casal em 11 dos casos (sem incluir as gestantes solteiras que foram abandonadas por haverem engravidado).

Quanto aos problemas estudados, o item atitude do parceiro aparece no Quadro I, em anexo, com freqüência, e relacionado a seu procedimento perante a família, emprego, gravidez, ou a diferença de opiniões, dificuldades financeiras e até a comportamentos mais íntimos como o relacionamento sexual, fato que constatamos nos relatos de 13 pacientes.

Podemos constatar, ainda, que as alterações sexuais, das quais são encontrados exemplos no Quadro II, em anexo, estão presentes em 22

- Para efeito de uniformidade utilizaremos os termos casal e conjugal, para designar indistintamente relaçóes de parceiros casados ou năo. 


\begin{tabular}{|c|c|c|c|c|}
\hline 晶 & 田 & 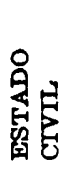 & 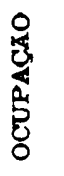 & PROBLEMA \\
\hline MG & 29 & $\mathrm{C}$ & PD & Desentendimentos causados pela gravidez. \\
\hline MLV & 25 & $\mathbf{C}$ & PD & Desentendimentos causados por diferenças de opinia.o. \\
\hline MHB & 28 & C & L & $\begin{array}{l}\text { Alteração sexual devidas ao ambiente e a atitude do parceiro em } \\
\text { face da gravidez. }\end{array}$ \\
\hline MA & 20 & $\mathrm{C}$ & PD & Alteração sexual devida a atitudes do parceiro (agressão). \\
\hline DM & 19 & C & PD & Alteraçăo sexual devida a desinformaçăo sobre o que é o bebe. \\
\hline SAS & 19 & $\mathbf{A}$ & PD & Alteração sexual devida ao bebê e a atitude do parceiro. \\
\hline IC & 17 & $\mathbf{A}$ & ED & Alteração sexual causada por atitudes do parceiro. \\
\hline MAP & 24 & $\mathrm{C}$ & $\mathbf{P D}$ & $\begin{array}{l}\text { Alteração sexual devida a pouco interesse pelo companheiro e com } \\
\text { à gravidez. }\end{array}$ \\
\hline FS & 24 & $\mathbf{A}$ & PD & Alteração sexual devida a desinteresse por sexo e pelo parceiro. \\
\hline ML & 24 & $\mathbf{A}$ & PD & Alteração sexual devida ao ambiente e a doença do parceíro. \\
\hline AS & 35 & $\mathbf{C}$ & PD & $\begin{array}{l}\text { Atritos causados pela atitude do marido devido a gravidez, alte- } \\
\text { ração sexual (medo de engravidar). }\end{array}$ \\
\hline $\mathbf{A F}$ & 20 & $\mathbf{C}$ & PD & Atritos causados pelo comportamento do parceiro devido à gravidez. \\
\hline $\mathrm{CH}$ & 25 & $\mathbf{C}$ & $\mathbf{P D}$ & Alteração sexual devido à desinformação. \\
\hline MFB & 19 & $\mathbf{A}$ & $\mathrm{PD}$ & $\begin{array}{l}\text { Desentendimento, brigas devidos a comportamento do parceiro (adi- } \\
\text { ção a álcool). }\end{array}$ \\
\hline IS & 34 & C & PD & $\begin{array}{l}\text { Atritos devido a atitudes do parceiro para com a tamilia (adiçăo a } \\
\text { ácool) e alteração sexual dele. }\end{array}$ \\
\hline EM & 30 & $\mathbf{C}$ & PD & Alteração sexual e dificuldades financeiras. \\
\hline CMB & 22 & $\mathbf{C}$ & $\mathbf{P D}$ & $\begin{array}{l}\text { Alteração sexual, relacionada a religlăo e atividade profissional do } \\
\text { marido. }\end{array}$ \\
\hline MRB & 20 & $\mathbf{C}$ & PD & Alteração sexual relacionada ao bebe e ao parceiro. \\
\hline $\mathbf{A T}$ & 18 & $\mathbf{C}$ & PD & Alteração sexual relacionada ao bebe. \\
\hline FBA & 22 & $\mathbf{C}$ & PD & $\begin{array}{l}\text { Desentendimento e agressividade do marido devido a interferéncia } \\
\text { de terceiros; e alteraçăo sexual. }\end{array}$ \\
\hline MFs & 39 & $\mathbf{C}$ & $P D$ & $\begin{array}{l}\text { Atritos devido a instabilidade do marido nos emprégos e adiçăo a } \\
\text { álcool. }\end{array}$ \\
\hline MAS & 23 & $\mathbf{A}$ & PD & $\begin{array}{l}\text { Preocupação, o parceiro é doente neurológico, desempregado (lavou- } \\
\text { ra) e nåo quer trabalhar na cidade por desentender-se com } \\
\text { os pais. }\end{array}$ \\
\hline AP & 36 & $\mathbf{C}$ & PD & Relacionamento tenso em decorrencia da gravidez. \\
\hline CR & 30 & $\mathbf{C}$ & PD & Falta de diálogo devido a diferenças de opiniăo. \\
\hline L.A. & 24 & $\mathbf{A}$ & $\mathbf{P D}$ & Desentendimentos devido a interferencia de terceiros. \\
\hline $\mathbf{A B}$ & 34 & $\mathbf{C}$ & $\mathbf{P D}$ & Alteração sexual (dispareunia). \\
\hline CS & 24 & $\mathbf{S}$ & $\mathbf{E D}$ & Abandono pelo parceiro. \\
\hline IB & 21 & $\mathbf{S}$ & $\mathbf{B}$ & Abandono pelo pal do bebe. \\
\hline DS & 22 & $\mathbf{A}$ & PD & Influêncla de tercelros, alteração sexual devida a doença do marido. \\
\hline EB & 30 & $\mathbf{C}$ & PD & Alteraçăo sexual relacionada com desinteresse por sexo. \\
\hline $\mathbf{Z B}$ & 21 & $\mathbf{A}$ & PD & Alteração sexual relacionada a medo de engravidar. \\
\hline ES & 30 & $\mathbf{C}$ & PD & Atritos devido a atitudes do parceiro para com a familia. \\
\hline AV & 19 & $\mathbf{C}$ & PD & $\begin{array}{l}\text { Alteração sexual devida a pouca convivência com o marido (ativi- } \\
\text { dade profissional). }\end{array}$ \\
\hline MA & 26 & $\mathbf{C}$ & $\mathbf{P D}$ & $\begin{array}{l}\text { Alteraçăo sexual relacionada a medo de engravidar e pouca convi- } \\
\text { vencia com o marido (atividade profissional). }\end{array}$ \\
\hline
\end{tabular}

TOTAL / MULHERES 34

\begin{tabular}{lll}
\hline $\mathbf{A}-$ Amardada & S - Solteira & ED - Empregada doméstica \\
C - Casada & PD $~$
\end{tabular}




\section{QUADRO II \\ RESUMO DOS RESULTADOS OBTIDOS SOBRE O RELACIONAMENTO CONJUGAL DAS PACIENTES.}

SENTIMENTOS, FATOS,

QUEIXAS RELATIVAS AOS PARCETROS

\section{MOTIVOS}

- Raiva, desapontamento com o parceiro (marido, amásio, companheiro).

- Preocupação com o futuro dos filhos.

- Sente-se nervosa, angustiada.

- Tem receio, de que o marido deixe de gostar dela; parceiro com clúmes pensa que ela não gosta maís dele.

- Ressentimento, médo, insegurança.
- O parceiro não demonstra interesse em regularizar a situação deles (casamento).

- O marldo depende financeiramente do pal.

- Ele não pensa em fixar residência, năo se preocupa com ela e com os filhos.

- Acha o marido indiferente as dificuldades pelas quais passam.

- O marido năo providencia condiçóes de habitaçăo que dêm privacidade ao casal.

- O marido não providencia habitaçăo só para eles.

- Passam dificuldades.

- O marido está relutante em includr os filhos na vida do casal.

- O marldo age como se losse solteiro.

- Não gosta do bairro onde moram.

- o parceiro não regulariza a situação conjugal por interferência de familiares.

- Marido costuma se embriagar e, nesse estado, maltrata os filhos.

- Acha que, na opiniăo do marido, mulher é só para procriar.

- Está envergonhada por ter engravidado, tendo filhos já grandes.

- Tem diminuido seu entusiasmo afetivo sexual pelo parceiro.

- Acha o marido indiferente ao seu estado gravidico.

- O marido culpa-a pela gravidez.

- Culpa o marido por um abórto espontaneo anterior.

- o marldo abandonou-a grávida e fol embora com outra.

- o marido abandonou o filho e ela grávida.

- Considera o marido responsável pela gravidez.

- o parceiro não se preocupa em prover o sustento dela e do futuro bebé. 
- Sente raiva do marido.

- Discussões frequientes.

- Tem um relacionamento distante.

- Nervosismo, angústia.

- Receio de abandono.

- Atividade sexual comprometida por problemas exclusivos do parceiro.
- Culpa o parceiro pelos "estragos" na sua imagem corporal em decorrência da gravidez.

- Desde que engravidou o marido começou a beber e está agressivo.

- O ex-marido não lhe permite ver o filho e lhe faz ameaças.

- A irmã do parceiro causa-lhe muito aborrecimento.

- A sogra tumultua e controla excessivamente a vida do casal.

- A ex-mulher do parceiro interferia na vida do casal.

- Não gosta da profissão dele (tem vergonha).

- Casou-se (morar junto) somente para ter seu "canto"; sair da casa dos pais; fugir do ex-marido.

- O marido se embriaga frequentemente o lhe faz ameaças.

- Não gosta de gente da raça do parceiro.

- Tem pouco contato com o marido devido a atividade profissional deste.

- O parceiro é "fechado", muito "sêco".

-- O marido é doente e está descompensado.

- O parceiro está doente e resiste à cura.

- o parceiro toma drogas e ela não aceita esse hábito.

- Ela e o parceiro não compartilham das mesmas idéias sobre atividades e comportamento sexual.

- Não obtém sintonia com o parceiro na relação sexual, na freqüência e/ou na intensidade do prazer.

- Tem pouco ou nenhum interesse por relação sexual.

- Medo de engravidar.

- Medo de machucar o bebé.

- Desconforto da gravidez.

- Habitação inadequada.

- O parceiro a agride físicamente.

- O parceiro mantêm relações sexuais mesmo quando ela não quer.

- o marido $€$ mulherengo e não esconde o fato.

- Importência (devido a doença neurológica, alcoolismo).

- Doença venérea.

- Contatos sexuais pré-estabelecidos (atividades profissionais ou religião). 
dos casos apresentados e que elas estão vinculadas a desinformação do casal a respeito do assunto, atitude do parceiro perante a mulher e filhos, a inadequação do ambiente, interferência de terceiros, desinteresse por sexo e/ou pelo marido, atividade profissional e doença do companheiro, ao bebê e ao medo de engravidar. (Apesar de algumas mulheres já estarem grávidas, elas referiram que tinham aversão ao ato sexual anteriormente, por ele representar uma possibilidade de engravidar, e essa preocupação também estava subjacente em muitos casos de frigidez).

Observamos que há interligação das causas geradoras de atritos entre - casal, o que dificulta muito a obtenção de dados quantitativos; daí termos optado por efetuar uma análise mais acurada nos dados qualitativos, pois no momento nosso interesse volta-se mais para a compreensão dos motivos que levam a gestante e seu companheiro a relacionamento conflituoso. Ainda o Quadro II, em anexo, nos fornece maiores dados a respeito das queixas, fatos e sentimentos informados pelas pacientes, relativos a seu compenheiro, bem como dos motivos que os causaram.

\section{ANALISE E DISCUSSĀO DOS DESULTADOS}

Durante a assistência oferecida às pacientes, pudemos detectar a existência de vários motivos que lhes despertaram sentimentos e comportamentos desagradáveis, que culminaram em desentendimentos ou que potencializaram situações conflitivas, pré-existentes entre o casal.

Apenas para efeito de melhor análise desses motivos e de suas repercussões, decidimos agrupá-los de acordo com uma suposta origem, pois observamos que poderíamos considerá-los como estando relacionados a três aspectos, não exclusivos um do outro, e dependentes entre si:

A - Características pessoais dos parceiros, que incluem:

- maturidades dos pares

- valores adquiridos do meio (mitos, crenças culturais)

B - Caracteristicas interpessoais do relacionamento homem-mulher, que incluem:

- nível de comunicação

- qualidade do relacionamento afetivo e sexual do casal

- grau e qualidade das informações recebidas sobre as funções sexuais

$\mathrm{C}$ - Caracteristicas do meio, que incluem:

- fatores sócio-econômicos

- tipo de habitação

- privacidade do casal

Não enquadramos nesses aspectos o estado grividico como um item específico, por considerar que ele está presente nos três, causando alteraçōes em maior ou menor grau. 


\section{A - Caracteristicas pessoais dos parceinas}

A gravidez é um estado peculiar que afeta em maior grau a mulher e, indiretamente, o pai do bebê e demais familiares; isto porque nesse período ocorrem alterações profundas a niveis físicos, psíquicos, interpessoais e sociais, que irão interferir efetivamente no comportamento das pessoas envolvidas. Por isso a gestação é considerada um episódio crítico do desenvolvimento.

Na maioria dos casos assistidos, a gravidez não era esperada pelo casal, daí grande parte das gestantes, inclusive de alguns companheiros, a rejeitarem assim que ela era confirmada. Os motivos alegados referiam-se à falta de condições sócio-econômicas para assumirem mais esta responsabilidade.

Constatamos que a primeira gravidez do casal geralmente fora aceita por ambos (pai e mãe), independente da situação financeira do casal, de ser ou não esperada e até mesmo quando a situação conjugal não estava legalizada.

Para D'ANDREA ${ }^{2}$, um fator importante numa ligação é que o casal esteja consciente do que essa união representa, ou seja, de que haverá mudança de "status" e papéis sociais, renúncia ao descompromisso da vida de solteiro, recanalização dos afetos e responsabilidade sexual e social para com um companheiro com o qual se compartilharão todas as decisões futuras, importantes ou não.

É com a notícia da gravidez que o casal toma consciência dessas responsabilidades e de que instituíram de fato os laços familiares, pois tornar-se-á necessário prever a inclusão de mais um membro na sua distribuição de afeto, de espaço físico, dos bens e até da alimentação; assim, em todo o legado da família, bem como nas futuras decisões do casal, deve estar incluída a participação desse novo ser.

Durante $o$ atendimento percebemos que a atitude positiva do companheiro em face da gravidez interferiu grandemente para a aceitação da mesma pela gestante; se ele demonstrasse pouco interesse pelo fato e despreocupação pela mulher, ela sentia-se ansiosa; algumas demonstravam raiva pelo companheiro, irritabilidade e até tristeza e choro; isto porque o desinteresse do companheiro era interpretado como pouco afeto para com elas e seu bebê, pois haviam aprendido do meio cultural que "mulher grávida" deve ter tratamento especial.

Constatamos, em algumas situações nas quais um dos parceiros não queria a gravidez, que o membro que não a aceitava culpava o outro pelo acontecimento, pois, na sua fantasia, acreditava ter o outro capacidade de conceber sozinho, sendo o "culpado", alvo da hostilidade do parceiro ou parceira. Observamos que o fato estava associado ao desconhecimento de como se processa a gravidez e talvez ao medo de assumir a responsabilidade de ser mãe ou pai.

Percebemos nessa eventualidade que um dos cônjuges queria eximir-se da responsabilidade do ato, demonstrando assim uma atitude de 
intransigência que confirmava para nós, o grau de desconhecimento da concepção e também o despreparo emocional em face da gravidez.

Observamos, neste estudo, que a responsabilidade sexual de que fala D'ANDREA ${ }^{2}$, como pré-requisito do casal maduro, com freqüência recaía sobre um dos cônjuges, mais especificamente sobre a mulher. Além disso, o discernimento a respeito das implicações da vida em comum com um parceiro do outro sexo não era muito freqüente entre as nossas gestantes e seus companheiros. Deduzimos essa idéia considerando os motivos que algumas pacientes mencionaram como justificativa para se casarem ou se unirem a um parceiro: desentendimento com os pais, ambiente familiar tumultuado, vontade de ter seu próprio "canto", ter alguém com quem ficar, valores diferentes daquele da família e outros que indicaram o desejo de fuga de uma situação não aceita, ou difícil, ou, ainda, uma situação de abandono.

Assim, pensamos que a pessoa que se tenha unido a um parceiro para se afastar de uma situação insustentável, sem levar em conta o afeto e o respeito mútuo necessários, colocar-se-á em uma situação de receptor de benefícios, à espera de que a vida conjugal lhe satisfaça os desejos sem exigência de cumprimento de deveres. Estes casos demonstram que tanto o homem quanto a mulher continua mantendo o seu papel de "filho", recusando-se a assumir o novo papel, ou seja, de "marido" ou "mulher" e, posteriormente, de "pai" ou "mãe", com suas conseqüentes responsabilidades. Essa posição tomada por um dos cônjuges faz com que o elemento receptor responsabilize o outro por todos os atos, por ele considerados desagradáveis, que ocorrem na vida em comum de qualquer casal.

MEAD 6, ao estudar a tribo Mundugomor, na Nova Quiné, relata uma situação parecida nessa cultura. A autora menciona que, quando ocorria a gravidez, o homem irritava-se com o fato, dirigindo ofensas à mulher, amaldiçoando-a pela pouca eficácia de sua "mágica anticoncepcional"; quanto a ela, a gravidez só lhe causava transtornos, pois era sinônimo de privação sexual, situação que a deixava à mercê da ira, do repúdio e da infidelidade do marido.

A diferença de valores é outro ponto de atrito importante entre os pares. Observamos que certas situações como ter "um canto" privativo, ter moradia fixa, ter regularizada a sua situação conjugal, são valores para algumas gestantes e não o são para os seus respectivos companheiros.

\section{B - Caracteristicas do relacionamento interpessoal}

Os motivos que levaram ao aparecimento de conflitos na vida conjugal da gestante também estão relacionados à qualidade da comunicação que se estabelece entre ela e o seu parceiro. As queixas que nos foram relatadas dizem respeito a companheiros despreocupados com a família, ou aditos a drogras, ou que costumavam embriagar-se, destruir os pertences do casal e até maltratar a mulher e os filhos, ou caráter violento 
completamente insensiveis aos valores, desejos ou necessidades da companheira.

As situações apontadas todavia, não dizem respeito apenas ao companheiro, algumas vezes o problema era da mulher, como, por exemplo no caso em que o companheiro a tratava bem, provia o sustento da família, assumia as responsabilidades de pai e, apesar disso, a mulher não se sentia satisfeita e criava atritos com ele por achar que a profissão dele era "humilde", e em conseqüência, ela o ignorava quando o encontrava desempenhando suas funções. Em outras situações a esposa reclamava que ele não lhe dava a atenção esperada quando voltava do trabalho, mesmo quando ciente de que a atividade profissional ou a jormada de trabalho do marido era extenuante; assim, procurava chamar a atenção do marido através de comentários ou atitudes que ela sabia, previamente, não lhe agradarem.

Os episódios em que o parceiro não aceitou a gravidez da mulher e culpou-a pelo acontecido despertaram na gestante sentimentos de culpa, da mesma forma que comentários depreciativos sobre as mudanças corporais decorrentes desse estado, influíram nos sentimenos que a mulher tinha a respeito de sua auto-imagem. As atitudes do marido sobre a gravidez, de apatia, indiferença, de rejeição, ou quando a figura do pai do bebê não oferecia a segurança de um vínculo estável à mulher, ela se sentia revoltada, desanimada ou insegura, pois a responsabilidade da gravidez recaia totalmente sobre ela.

Notamos que nessas situações a gestante desenvolvia maior ou menor aversão pela presença do marido inclusive pela atividade sexual, sendo que esta atitude gerava no companheiro fantasias de ciúme e desconfiança, de traição, por parte dela.

$\mathrm{Da}$ mesma forma, ocorreram alterações no relacionamento afetivo e sexual naquelas gestantes que culparam seus companheiros pela gra videz, ou por considerá-lo responsável indireto pelos «estragos» feitos no seu físico.

Percebemos o quanto esses comportamentos e atitudes dos parceiros, de um para com o outro, contribuíram para o aparecimento de desentendimentos, brigas e inibições da sexualidade em graus diversos; especificamente na mulher, observamos desde o desinteresse, até a frigidez e a aversão pela relação sexual.

A constatação de problemas de ordem sexual foi quase exclusivamente nas mulheres; isto porque elas os relataram durante as entrevistas; todavia não podemos afirmar que seus companheiros năo os apresentassem, também, pois várias gestantes nos deram informações ou indícios de que eles tinham distúrbios de ordem sexual, como era o caso dos alcoolistas.

Conseguimos a colaboração de apenas três maridos das pacientes dois dos quais estavam muito preocupados com seu problema, um com ejaculação tardia, outro com doença venéria e medo de câncer; o terceiro 
aparentemente preocupava-se apenas com a esposa; no entanto, sua atividade sexual era extremamente influenciada por suas conviç̧ões religiosas, de tal forma que julgamos tivesse o paciente algum tipo de problema e que ele usasse a religião como argumento para desculpar-se perante a mulher; acreditamos que o «stress» provocado pela atividade profissional também influenciasse no rigor com que estabelecia a atividade sexual do casal, pois, segundo ele e a esposa, o local de trabalho era insalubre (quente, baru lhento, com modificações mensais no turno de trabalho) a ponto de estar com a aqüidade auditiva comprometida e distúrbios no sono (insônia).

Dentre as pacientes que apresentaram alterações sexuais, houve aquelas que referiram, abertamente, não aceitar anteriormente a gravidez.

A relação sexual como manifestação de afeto; para elas era algo «sujo», «traumatizante» que não lhes causava prazer algum. Outras mostraram pouco interesse, referindo que nunca tinham tido sensação no ato sexual, fato que, aparentemente, não lhes gerava ansiedade ou preocupação; entretanto, algumas pacientes que, no passado, já haviam experimentado sensação prazeirosa durante o ato sexual mostraram preocupação e algumas até revolta por se sentirem excluídas desse prazer e não compartilharem da sensação do parceiro; todavia, percebemos, na maioria desses casos, que as paciente se preocupavam com o problema não por sua própria causa, mas por meio de perderem o afeto do companheiro e de serem abandonadas.

Para a maioria das pacientes a relação sexual significava a possibilidade de uma gravidez; assim, durante a relação sexual, a mulher não conseguia desligar-se dessas idéias, as quais a deixavam tensa e ansiosa, com receio de que a possibilidade de ocorrer a gravidez se tornasse um fato concreto. Ficou evidente que as multíparas, com freqüência, usavam o coito interrompido como prática anticoncepcional, agravando suas dificuldades no relacionamento.

As idéias sobre freqüência, horário e variações de relacionamento sexual, bem como o comportamento durante $o$ ato em si nem sempre foram 1 compartilhadas pelo casal.

Algumas gestantes entrevistadas queixavam-se de que o companheiro queria manter relações sexuais durante o dia, e isso as revoltava, especialmente se ele estivesse sem ocupação; a justificativa para essa atitude era de que, nesse período, estavam sobrecarregadas de serviço.

Outros motivos de queixas se referiam ao fato de somente manterem relações sexuais em dias marcados, especialmente no fim de semana, em decorrência da atividade ocupacional do companheiro; algumas gestantes se mostraram mais compreensivas, entendendo essa atitude do marido como normal, pois percebiam que durante a semana ele estava muito cansado. De qualquer maneira essa prática, mesmo quando justificada, suprimia de certa forma a espontaneidade do ato.

Também foram causa de desentendimento as «novidades» que o companheiro queria introduzir, especificamente o coito anal. As gestantes 
não o aceitavam e encaravam essa prática como uma agressão, mesmo aquelas que se submetiam à vontade do marido.

Quanto ao comportamento durante o relacionamento sexual, muitas referiam que «estavam para servir» ao companheiro; no entanto algu mas mais jovens reivindicavam suas sensações prazeirosas e queriam manter relações apenas quando estivessem com vontade.

Observamos casos de pacientes com distúrbios da área sexual, que acreditamos estarem vinculados a experiências ocorridas na infância; (castigos maternos em decorrências de brincadeiras masturbatórias; culpas por terem denunciado à mãe que os irmãos se masturbavam; mães que lhes deram informações deturpadas e negativas a respeito da função dos genitais).

Observamos, também, que certas pacientes, que haviam estabelecido uniōes conjugais unicamente para fugir de situaçōes opressivas, tais como pais controladores, ausência de espaço físico ou privacidade na casa paterna, ex-marido violento, apresentavam maiores conflitos com seus companheiros, mesmo quando este, segundo comentário delas, «não deixava faltar nada», dentro das possibilidades do casal. Essas gestantes apresentaram alteraçōes sexuais que iam desde indiferença, desinteresse até a aversão ao ato sexual.

Outros aspectos a serem considerados são os preconceitos «tabus» e vergonhas relacionadas aos conceitos sobre a sexualidade; por exemplo, a vergonha da mulher de mais de 35 anos expor sua gravidez perante os filhos e a sociedade; essas mulheres sentiam-se envergonhadas pois o concepto representava a confirmação de que ainda mantinham vida sexual; o preconceito aí se consubstanciava no fato de, em nossa sociedade, só as mulheres jovens terem direito à sexualidade (mulheres «novas e bonitas»).

Além do que já foi citado, observamos que todas as pacientes argumentavam serem as alterações na sua sexualidade devidas ao estado gravídico, embora elas mesmas não estivessem convencidas disso, pois, em seguida, pediam a nossa confirmação; as alterações na sua sexualidade envolviam vários fatores $\mathrm{e}$, antes de atribuirmos a causa dos problemas sexuais da gestante ao seu estado gravidico, foi necessário investigar como era o relacionamento sexual dessa paciente com o seu companheiro antes de ficar grávida.

Acreditamos que, dentre os fatores responsáveis pela falta de prazer da mulher no ato sexual, estão a desinformação a respeito dos órgãos genitais e de suas funções; idéias depreciativas sobre o ato sexual obtidas de pessoas significativas no decorrer de sua vida; mitos culturais; par. ticipação da mulher no ato e as «regras de conduta» a serem seguidas nas relações sexuais; atitude de proibição sobre o conhecimento do corpo e a aceitação da própria sexualidade; dificuldade da mulher em expressar verbalmente seus desejos e sentimentos ao companheiro; ressentimento e mágoa entre o casal devidos a outros problemas de relacionamento.

Verificamos que as pacientes habitualmente ou anteriormente submetidas pelo parceiro a experiências traumáticas tais como agressão física, 
aborto após agressão, não aceitação da gravidez, humilhações ou vida difícil decorrente da indiferença do marido freqüentemente utilizavam a frigidez como forma de expressar o seu descontentamento; era, de certa forma, a maneira de puní-lo, pois a não participação da mulher no ato sexual o deixava perturbado e lhe provocaria ciúmes, uma vez que se sentia inseguro do afeto da companheira.

A respeito das alterações sexuais da mulher BERGLER, citado por LANGER ${ }^{5}$, menciona que há dois tipos de frigidez, a «obrigatória» e a «facultativa». A primeira refere-se à incapacidade absoluta da mulher em alcançar o orgasmo, e a segunda de as mulheres que podem alcançar o orgasmo, dependendo do companheiro e das circunstâncias. Para LANGER ${ }^{5}$, toda mulher até certo ponto é facultativamente frígida, uma vez que não alcançará o orgasmo em situações adversas com um companheiro inadequado.

A própria situação gravídica e a eminente vinda do bebê foi um fator que propiciou o aparecimento de atritos em alguns relacionamentos conjugais, pois o fato culminou em mudanças no comportamento de alguns companheiros, tais como aventuras extra-conjugais, abandono da parceira, busca do alivio da ansiedade na adição ao álcool e em condutas agressivas (verbais e físicas), incluindo sugestão de doação do bebê; estas circunstâncias deixavam a mulher apreensiva quanto ao futuro do seu relacionamento e à aceitação do filho pelo companheiro.

$O$ bebê também motiva alterações nas atividades sexuais do casal (mesmo quando há entendimento entre eles), pois, no dizer de SOIFER ${ }^{10}$, «Nenhuma gravidez é totalmente aceita nem totalmente rejeitada», e esse estar ambivalente em relação ao bebê expresso pelos pais, através da formação reativa de excessivo zelo para com ele; isso provoca o desinteresse, a inibição da vontade de manter relações sexuais; e quando o contato ocorre este é carregado de sentimentos de culpa, impedindo que a relação seja satisfatória para um deles e às vezes para ambos.

Segundo LANGER ${ }^{5}$, outro fator que pode interferir é a incompatibilidade entre maternidade e sexualidade. A idéia da mulher grávida ser vista como assexuada, por estar desempenhando uma função sublime, poderia causar diminuição e até desinteresse total pelas atividades sexuais.

A mulher traz, além disso, uma enorme bagagem cultural inversa, que lhe ensina dever abster-se de relações sexuais nesse periodo, pois elas poderiam provocar aborto, morte do bebê, má-formação, parto prematuro... Somente uma paciente nos relatou que a sogra a havia orientado que deveria manter o maior número possível de atos sexuais, pois isso lhe «facilitaria o parto».

Assim, a preocupação excessiva com o bebê durante o ato sexual também está relacionada a fatores culturais (mitos, crenças religiosas), referentes à proibição do contado sexual durante a gravidez, provenientes das informações que a gestante e o companheiro recebem do seu meio am biente próximo (família, vizinhos, etc.). 
Os relatos de estudos feitos por $\mathrm{MEAD}^{6}$, em tribos primitivas, mencionam que em algumas delas o casal deveria abster-se de manter relações sexuais a partir do momento em que apareciam na mulher os primeiros sintomas indicadores da gravidez. Em certas culturas essa conduta estava incluida dentro de uma série de medidas que visavam impedir atividades causadoras de dano ao bebê ou perturbadoras do seu «sono»; em outras, a proibição decorria da crença de que outros contatos sexuais ocasionariam o desenvolvimento de gêmeos.

Encontramos um pararelo a essas crenças das tribos primitivas nas gestantes cujo marido, assim que a via grávida, não mantinham mais relações sexuais, alegando que era «pecado», pois perturbavam a criança. A desinformação, a ansiedade dos cônjuges, a inadequação de condutas, mais os mitos culturais envolvidos na gravidez contribuem pois, para a existência de alterações no relacionamento do casal, devido à preocupação com a segurança do feto, ou ciúmes ou medo das responsabilidades implícitas nas funções de pai ou de mãe de um bebê, seja este o primeiro filho ou não.

\section{$\mathrm{C}$ - Caracteristicas do meio}

Pudemos verificar, durante o nosso atendimento, os problemas relacionados com a falta de habitação, que traziam como conseqüência sérios conflitos entre os membros das famílias, destacando-se a interferência de terceiros, quando o casal habitava em casa com outros parentes (sogra, pai, irmãos e outros) a fim de diminuir seus gastos.

Essa interferência de terceiros foi um ponto de atrito bastante im. portante entre o casal. Uma das causas principais desse atrito dizia respeito a pais possessivos, que não aceitavam ou estimulavam a independência de seus filhos; a gestante não se sentia incentivada a criar sua própria família e, às vezes, até considerava sua intimidade invadida por esses elementos, os quais impediam a privacidade do casal, inibindo manifestações físicas de afeto.

Ao mesmo tempo, encontramos que a interferência de familiares também pôde ser benéfica para a gestante, na medida em que lhe proporcionava consolo e apoio. Observamos este fato nas pacientes solteiras que haviam engravidado, sem expectativa de manter vínculos com o fai do bebê. Nestes caso, a figura do pai, da mãe, de ambos ou até de um irmão (que lhes demonstrasse compreensão e aceitação do fato) permitia que essas pacientes encarassem o futuro com mais otimismo e menos revolta.

Para CAPLAN 1 , o intercâmbio de amor, afeto e apoio que a família pode proporcionar aos seus membros é importante para cada um desses indivíduos, quando estão experimentando dificuldades, pois é a famılia que os fortalece e os ajuda na liberação das tensões, na manutenção de ansiedade dentro de limites manejáveis até que essa pessoa elabore uma solução. Caso contrário, essa família pode ser uma fonte de acréscimo de tensão e trará dificuldades extras para esse individuo na solução dos seus problemas. 
Por outro lado, também pudemos sentir as dificuldades e os sent1mentos de solidão, abandono e desamor daqueles gestantes que foram abandonadas por ex-companheiros; uma situação penosa e difícil de ser aceita quando a pessoa se sentia privada da presença do elemento que, na maioria das vezes, era encarado como o agente de sua segurança (econômica e afetiva).

Verificamos, ainda, nos casos de parceiros separados ou desquitados que iniciavam novas ligações afetivas, situações de conflito criadas pelos ex-companheiros que, ao tomarem conhecimento dessas novas uniões de seus pares, tumultuavam direta ou indiretamente, através dos fllhos, a vida do novo casal. Isto gerava sentimentos de culpa nesse pai ou mãe, no atual parceiro e, às vezes, em ambos.

Afora isso, pudemos observar: falta ou instabilidade no emprego com repercussão de insegurança e dependência dos familiares; ausêncla de perpectiva quanto ao futuro e a busca de soluções para os problemas, através de métodos inadequados para dar vazão a seus sentimentos de ansiedade e frustração, tais como o alcoolismo; instabilidade de vínculos entre os parceiros, na maioria das vezes por falta de condições que permitissem legalizar esta situação devido a ausência de orientação, poucos recursos financeiros, excesso de entraves burocráticos, os quais dificilmente serão superados por essa população por não ter um suporte (acompanhamento de um profissional que lhe assegure os seus direitos como cidadão); e situação irregular de filhos (registros, pensão alimentícia, etc.), em decorrência dessas situações conjugais indefinidas e ou não legalizadas. Isto contribuia e muito para aumentar a instabilidade do casal.

MOFFATT ${ }^{9}$ faz algumas considerações a respeito da instabilidade de certa camada da população, a qual ele denomina de «os pobres», «os humildes», na qual poderíamos incluir a maioria dos nossos casos. Segundo o autor, essa faixa não pertence a determinada classe social e está sujeita a três tipos de nomadismo - o geográfico, o laboral e o marital.

Para esse autor, toda classe social busca a estabilidade geográfica ou o sentimento de pertencer a algum local, a um bairro; quando isso não acontece, o indivíduo vivencia instabilidade e desamparo. $\mathrm{O}$ "possuir» um local para morar, o «sentir-se» parte dele são símbolos que ajudam o seı humano - da mesma forma que o sobrenome, o corpo e a função laboral - a estruturar a própria identidade.

O ser «dono do seu» confere ao indivíduo segurança; todavia, a habitação própria é conseqüência da continuidade laboral, ou seja, da estabilidade no emprego; assim, os induviduos que não têm ocupação definida ou um emprego fixo com garantias de continuidade, ou mesmo aqueles que passam por longos periodos de desemprego, constituem uma população que se sujeita a qualquer serviço, independente do horário e das condições de trabalho oferecidos.

As oscilações no salário obrigam a familia a adaptar-se a mudanças freqüentes no seu padrão de vida, impelindo-os na busca de moradias 
cada vez menores e mais distantes do convívio de pessoas conhecidas, do seu trabalho e dos núcleos urbanos com melhoramentos (condução, serviços de assistência à saúde, supermercados, etc.).

Os longos periodos de ausência do seio familiar, aos quais esses elementos (homem ou mulher) estão sujeitos em decorrência da distância entre a habitação e o emprego, vão deteriorando as relaçōes afetivas fa. miliares, perdem-se os vínculos e a responsabilidade vai se tornando um encargo pesado, o que desperta sentimentos de fuga e propicia condições para a evasão; daí MOFFATT ${ }^{9}$, considerar o nomadismo marital como conseqüência dos outros dois - o geográfico e o laboral.

Por outro lado, as características da habitação são muito importantes para o estabelecimento de relações sadias entre os membros da família.

Em nossa população, as queixas referiam-se a habitação com poucos cômodos, casa sem forro, amontoado de pessoas que dormiam sob um mesmo teto (filhos, cunhados, sogros) e até no mesmo quarto do casal; à parte as inibições do casal, decorrentes dessa convivência, há o problema sério de os filhos observarem o ato sexual dos pais. Ainda para esse autor, a proximidade de muitas pessoas (crianças e adultos) dormindo num mesmo local induz ou facilita contatos incestuosos.

Observamos, também, na estrutura familiar da população estudada que, para a gestante (mesmo na ausência de vínculos legais), se as atitudes do companheiro (prover alimentos, manutenção financeira, assumir o registro dos filhos, etc.) lhe davam garantia de um compromisso estável, ela não se mostrava tão preocupada em regularizar sua situação, pois em seu meio cultural o amásio tem a conotação de marido. Entendemos, pois, a insegurança da paciente quando não observava estas atitudes por parte do amásio; sentia-se ameaçada de possivel abandono. com medo de ficar só e com a responsabilidade dos filhos; temia também a rejeição da sociedade por não ter a proteção do homem.

Diante de tudo isso, entendemos porque a paciente se sujeita a manter situações conjugais conflitivas e persistir em manter esses vínculos, os quais muitas vezes, lhe trazem mais prejuizos do que benefícios, pois para o seu meio cultural esta separação tem a mesma conotação do desquite ou divórcio, com as conseqüentes críticas advindas dos preconceitos em relação à mulher abandonada.

Estes achados vêm confirmar as considerações feitas por CAPLAN ${ }^{1}$ a respeito do meio cultural em que o indivíduo se desenvolveu, quando menciona que «aquilo que os outros esperam da conduta de uma pessoa influi profundamente sobre suas ações e sobre os sentimentos acerca de si mesma».

Percebemos, então, que os aportes sócio-culturais e econômicos são importantes para a determinação de situações conflitivas, dando à gestante e ao seu companheiro tanto condições de progresso quanto de bloqueio, os quais poderão intervir de maneira efetiva no seu relacionamento, na manutenção dos vínculos familiares e no desenvolvimento normal da gravidez. 


\section{CONSIDERAÇOES FINAIS}

Pudemos observar a complexidade do assunto devido às inúmeras variáveis envolvidas, que incluem desde os aspectos pessoais, o relacionamento interpessoal dos cônjuges, até os fatores incluídos no seu meio social (habitação, emprego, codições financeiras).

O tema, pelas suas peculiaridades, é delicado e de difícil abordagem; exige que o enfermeiro ou qualquer outro profissional de saúde além de ter conhecimento dos assuntos, seja compreensivo de forma a possibilitar que a paciente expresse problemas da sua intimidade e suas emoções, sem receber manifestações de recusa ou julgamento crítico direto à sua exposição por parte do profissional.

Nossa experiência mostrou que a gestante esperava ser ouvida pela enfermeira com interesse e seriedade, e obter o alivio para suas tensõ€s através de esclarecimentos e orientação que a ajudassem na resolução dos seus problemas.

Percebemos que o relacionamento da gestante com seu parceiro sofreu algumas alterações, pois a gravidez funciona como um agente despertador ou potencializador de problemas pré-existentes, manifestados ou não, por incluir um fato novo que é a vinda do bebê, o qual gera muitas mudanças (físicas, psíquicas e sociais), despertando novas emoções e dificuldades.

Este trabalho suscitou dúvidas e apreensões, pois, passamos a perceber a gestante sob um enfoque mais amplo do que aquele de que normalmente ela é alvo de investigação. Muito se tem falado sobre os cuidados com a gravidez, mas pouco se fala sobre a MULHER grávida e muito menos sobre o seu companheiro; ambos são pessoas que podem estar passando por experiências de vida não muito agradáveis que sofrem as agruras de conviverem com a insegurança da instabilidade da união, do emprego, da habitação, enfim da incerteza quanto a suas expectativas de um futuro melhor.

Percebemos o quanto essa situação influencia o relacionamento conjugal da paciente com o seu companheiro, tornando o seu convívio aind mais difícil. Muito se tem falado sobre sexualidade ultimamente, nos di versos veículos de informação, todavia parece-nos que o tema tem sido abordado sem levar muito em conta o contexto cultural e social dos indivíduos.

Durante nossa assistência percebemos que algumas crenças a respeito da atividade sexual, durante a gestação e após o parto, que haviam sido passadas por outras pessoas do convivio da gestante, eram preservadas e quando isso não ocorria, a paciente sentia-se angustiada por não as estar mantendo com ela; diminuição ou supressão da atividade sexual, ou aumento da atividade sexual («fortalecia os músculos»), e o resguardo.

Da mesma forma interferiam nas condições sócio-econômicas, pois uma habitação inadequada, sem conforto ou privacidade, o desemprego ou 
a instabilidade era fatores que dificultavam que o casal utilizasse o sexo como uma expressão mais íntima de afeto.

O tema nos preocupa, também, do ponto de vista da assistência de enfermagem, pois já que o assunto envolve o aspecto sexualidade, faltam-nos dados a respeito de como os enfermeiros têm lidado atualmente com os problemas sexuais dos seus pacientes. A enfermagem continua ignorando ou abordando superficialmente o aspecto sexual do seu paciente? Que tipo de conhecimentos e formação damos aos alunos de enfermagem a esse respeito?

Entendemos que essas questões são importantes para a assistência de enfermagem aos pacientes como um todo, homens e mulheres, gestantes ou não, pois acreditamos que, dependendo da nossa compreensão acerca do assunto, haverá em nós opiniōes e atitudes que farão refletir no paciente a maior ou menor tolerância do profissional, e que poderão permitir que ele aborde, durante a assistência, seus problemas sexuais.

Estamos cientes de que ainda há muitas dúvidas para serem sanadas e acreditamos que haja mais considerações a serem feitas, pois o nosso intuito com este trabalho não é o de esgotar o assunto, e sim trazê-lo à tona para discussão e elaboração de pesquisas mais amplas.

LUIS, M.A.V. Considerations about the marital relationship of the pregnant woman. Rev. Esc. Enf. USP, São Paulo, 20(2):125-142, 1986.

The author analyses the difficulties a woman faces in her conjugal relationship when she is pregnant and emphasize the complexity of the variables involved in the origins of the problem. She also discurses the importance of the attitude of the personnel in dealing with these patients.

\section{REFERENCIAS BIBLIOGRAFICAS}

1. Caplan, G. Princípios de psiquiatria preventiva. Buenos Aires, Paidós, 1966.324 p.

2. D'ANDRkA, F.F. Desenvolvimento da personalidade: enfoque psicodinâmico. São Paulo, DIFEL, 1978. $184 \mathrm{p}$.

3. Defutsch, H. La Psicologia de la mujer. 2. ed. Buenos Aires, Losada, 1953. v.2.

4. JACOBSON, G.; STRICKLER, M.; MORLEY, W. Generic and individual approaches to crises intervention. Am. J. Public Health, New York, 58(2):339-42, Feb. 1968.

5. LANGER, M. Maternidade e sexo. Porto Alegre, Artes Médicas, 1981.

6. LUfS, M.A.V. Assistência de enfermagem a gestantes com ênfase em sua saúde mental. Rov. Paul. Enf., Såo Paulo, 5(2):85-8, abr./jun., 1985.

7. MALDONado, M.T. Psicologia da gravidez: parto e puerpério. Petrópolis, Vozes, 1976. $118 \mathrm{p}$.

8. MEAD, M. Sexo e temperamento. São Paulo, Perspectiva, 1969. 316 p.

9. MOFFATT, A. Psicoterapia del oprimido: ideologia y tecnica de la psiquiatria. 3. ed. Buenos Aires, ECRO, 1975.

10. SOIfer, R. Palcologia da gravidez, parto e puerpério. Porto Alegre, Artes Médicas, 1980. $124 \mathrm{p}$. 